\title{
THE POTENTIAL CONVENTION OF GARLIC AND BLACK SEED DIFFERENT EXTRACTS AS AN EFFECTIVE TREATMENT OF CRYPTOSPORIDIUM SPP. : AN EXPERIMENTAL STUDY
}

By

\author{
HESHAM A. SADEK ${ }^{1}$, SALMA M. ABDEL-RAHMAN ${ }^{2}$, HANNA Y. BAKIR ${ }^{2}$, \\ MOHSEN I. ARAFA ${ }^{1}$, AHMED A. AHMED ${ }^{3}$, AHMED A. GAREH ${ }^{4}$, \\ AND MONA M. GABER ${ }^{2 *}$
}

Department of Parasitology ${ }^{1}$, Animal Health Research Institute, Assiut, Department of Medical Parasitology ${ }^{2}$, Faculty of Medicine, and Department of Pharmacognosy ${ }^{3}$, Faculty of Pharmacy, Assiut University ${ }^{2,3}$ and Department of Parasitology ${ }^{4}$, Faculty of Veterinary Medicine, Aswan University, Postal code, 71515, Egypt $\left({ }^{*}\right.$ Correspondence :monahadea@gmail.com, monagaber@med.aun.edu.eg ORCID: 0000-0002-1735-0168)

\begin{abstract}
The study investigated the effect of garlic (Allium sativum) and black seed (Nigella sativa) extracts products as treatment of Cryptosporidium infection in experimental mice in comparison to Nitazoxanide (NTZ). Forty-eight male Swiss Albino mice divided into 8 experimental conditions; G1-8, the first seven groups received $1.5 \times 10^{5}$ Cryptosporidium spp. oocysts on $1^{\text {st }}$ infection day. The first group included mice treated with garlic juice; in G2, G4 \& G5, mice were treated with black seed oil, alcoholic extract of black seed and alcoholic extract of black ariel parts respectively. In G3 mice were treated with garlic \& black seed oil mixture, while G6 mice treated were with Nitaxanoide. Besides G7 were infected untreated (+ ve control); and G8 were neitherinfected nor treated ( - ve control); From $2^{\text {nd }}$ day post-infection, pooled fecal samples of each group were collected daily to assess each extract efficacy as compared with NTZ and both +ve and -ve controls by calculating oocyst excretion pattern. The comparison between number of oocysts shedding rates among different treatment groups showed that the efficacy of NTZ was the highest $(76.1 \%)$ followed by $N$. sativa oil $(75.8 \%)$ followed by mixture of garlic and black seed oil (75.4\%), alcoholic black seed extract (75.1\%); alcoholic arial extract (74.7\%) and the lowest was garlic juice (73.1\%). Although both A. sativum and all $N$. sativa extract products showed a great degree of efficacy in reducing Cryptosporidium spp. oocysts excretions in the experimental animals compared to positive control, but without significance differences between them and preparation of both garlic, black seed and mixture with NTZ.
\end{abstract}

Keywords: Allium sativum; Nigella sativa; extracts; Nitaxanide; Cryptosporidium spp.

\section{Introduction}

Cryptosporidium is one of the opportunistic prevalent coccidian protozoan parasite (Fayer, 2008). Clinical features of cryptosporidiosis varied from abdominal pain, and anorexia (Fayer et al, 2000). The symptoms severity may wax and wane in patients according to the oocyst shedding intensity and host immunity (Current and Garcia, 1991).

Cryptosporidiosis drugs resistance to is one of most biological features as 200 regimen were tested (Miyamoto and Eckmann, 2015). Some exhibit promising effects but none was able to consistently control clinical signs or completely eradicate the infection. Some drugs reduced oocyst shedding, and also reduced environmental contamination exposure and infection of susceptible hosts (Shahiduzzaman and Daugschies, 2012).

Cryptosporidiosis clinical course depended largely on the host immune status, benefit of chemotherapeutic agents or immunotherapy against cryptosporidiosis. (Chen et al, 2007). Nitazoxanide (NTZ) is one of the chemotherapeutic option, available as a treatment for cryptosporidiosis; with a broad-spectrum parasiticidal agent approved by US FDA for treating diarrhea caused by Cryptosporidium in children and adults (Carey et al, 2003). NTZ treated diarrhea within 3 to 4 days and reduced oocyst shedding (Abdel Megeed et al, 2015). But, NTZ showed limited ability to reduce oocyst shedding in a mouse model and in a pig model high dose (150-250mg/ 
$\mathrm{kg}$ /day) reduced oocyst shedding and diarrhea (Theodos et al, 1998).

The ban on drugs due to resistance development, demanded alternative cryptosporidiosis treatment using phytogenic (Nouzarian et $a l, 2011)$ and herbal products received great reputation acquired more acceptability by consumers as natural products (Abdel-Hady et al, 2014). Toghyani et al. (2011) reported that the beneficial effects of bioactive plant ingredients in hosts included improvement of endogenous digestive enzyme secretion, activate immune responses, enhancement of appetite and food intake, with anti-parasitic, antioxidant (Tonkal and Morsy, 2008), antibicterial, and antiviral agents (Okello and $\mathrm{Ka}$ ng, 2019)

The plant essential oils were recognized as novel anti-parasitic agents which components have activity against gastrointestinal paras ites as nematodes (Benchaar et al, 2008), cryptosporidiosis parvum (Abouel-Nour et al, 2016). Abd El-Aziz et al. (2015) found that onion (Allium cepa) and cinnamon (Cinnamomum zeylanicum) oils affected Cryptosporidium spp. oocysts shedding due to $A$. $\mathrm{Ce}$ $p a$ and $C$. zeylanicum activity that helped in parasite elimination (Wei and Shibamoto, 2010). Extracts of garlic, pine-bark, blue berry, and curcumin showed anti-cryptosporidiosis action (Kim and Healey, 2001; Abu El Ezz et al, 2011; Toulah et al, 2012).

Garlic (A. sativum) showed good prophylactic and treatment action against cryptosporidiosis (Abdel Megeed et al, 2015). Amino acids as arginine, one of the active chemical constituents of garlic and organosulphate compounds as aliin and allicin, enzymes as allinase, minerals and vitamins $\mathrm{A}, \mathrm{B} 1 \& C$. allicin (Diallylthiosulphinate) a sulphate compound in garlic bulb showed physiological activity of dietary garlic (Ayaz et al, 2008).

Nigella sativa (kalvangi) black seeds were reported in medical treatment of hepatic and gastrointestinal disorders (ascites, jaundice, fever, flatulence, dysentery, diarrhea) and others including cough, paralysis, conjunctivitis, skin diseases intrinsic hemorrhage, am- enorrhea and local anesthetic action (Warrier et al, 2004), and anti-coccidian action (Baghdadi and Al-Mathal, 2011). Nigella oil contained saponin, nigellidine and nigellone and its seeds contained thymoquinone, monoterpenes such as p-cymene $\& \alpha$-pinene (Boskabady, 2002). Practically, N. sativa treated $C$. parvum infected calves (Nasir et al, 2013).

The study aimed to evaluate the effect of garlic (A. sativum) and black seed (Nigella sativa) extracts as compared with the conventional treatment for cryptosporidiosis in experimentally infected male mice.

\section{Material and methods}

Experimental infection: Cryptosporidium oocysts were collected from feces of naturally infected diarrheic calves of one day to 12 months of age from Assuit Veterinary field as proved by the modified acid fast staining method. Positive sediment samples were stored with $2.5 \%$ potassium dichromate solution at $4^{\circ} \mathrm{C}$ till needed (Abbassi et al, 2000). Discontinuous sucrose density gradient flotation technique was done (Arrowood and Sterling, 1987) to isolate and purify the oocysts. Purified ones were incubated with antibiotics (penicillin $5000 \mathrm{Iu} / \mathrm{ml}$, neomycin $1 \mathrm{mg}$ / $\mathrm{ml} \&$ amphotericin B $50 \mu \mathrm{g} / \mathrm{ml}$ ) at $37^{\circ} \mathrm{C}$ for $12 \mathrm{hrs}$ to kill contaminated microbial (Obiad et al, 2012). Oocysts number was estimated in the concentrated stock by hemocytometer and light microscope at 40X (Gaafar, 2007). Inoculum per mouse was $1.5 \times 10^{5}$ oocysts on $1^{\text {st }}$ infection day (Suresh and Rehg 1996).

Garlic preparation: Garlic was given to the mice as crude juice by separating fresh garlic bulbs, peeled, and washed with distilled water. The resultant bulbs $(500 \mathrm{gm})$ were crushed in a morter to get uniform consistency. Distilled water was added and pasted to get $1 \mathrm{~g} / \mathrm{ml}$ aqueous solution. Raw garlic juice was stored at $20^{\circ} \mathrm{C}$ until needed (Masamha et al, 2010). Stock solution was diluted by distilled water to have the working solution and dose was $50 \mathrm{mg} / \mathrm{kg}(\operatorname{Riad}$ et al, 2009).

Black seed preparation: N. sativa seed was extracted (Al-Naggar et al, 2003). N. sativa seeds $(0.5 \mathrm{~kg})$ were purchased from a local 
market, grounded and extracted with $n$-hexane by soxhlet apparatus to get $250 \mathrm{ml}$ pure oil after solvent evaporation (Mahmoudvand et al, 2014).

Alcoholic extract of black seed: Five kg powdered seeds were defatted with $n$-hexane and extracted in methanol, and evaporated to dryness in a vacuum with a rotatory evaporator to get $(160 \mathrm{~g})$ of the methanolic extract (MENS). MENS administered to mice as $1.25 \mathrm{~g} / \mathrm{kg}$ (Mahmoudvand et al, 2014).

Aerial parts extract: Seven $\mathrm{kg}$ of $N$. sativa dried aerial parts were extracted with methanol to get $100 \mathrm{~g}$ dried extract of which a stock solution was prepared and given to mice as $1.25 \mathrm{~g} / \mathrm{kg}$ (Farah et al, 2004).

Nitaxanide preparation: Mice received $\mathrm{Cr}$ yptonaz (Copad Pharma, Egypt) orally in a dose of $25 \mathrm{ml}(500 \mathrm{mg}$ ) every $12 \mathrm{hrs}$ (Abdel Megeed et al, 2015

Animals: Forty-eight male Swiss Albino mice, aged 3-5 weeks, weighed 25-30gm, were obtained from the animal house, Faculty of Medicine, Assuit University. Direct wet saline smear, iodine and Sheather's sugar flotation method were used to exclude any parasites (Garcia and Brucker, 1997). Mice were divided into 8 groups of 6 mice each. 1 - Infected treated group; includes 6 subgroups (G1-G6), G1: Mice treated with garlic juice, G2: Mice treated with black seed oil, G3: Mice treated with garlic \& black seed oil mixture, G4: Mice treated with black seed alcoholic extract, G5: Mice treated with black ariel parts alcoholic extract, G6: Mice treated with Nitaxanoide. 2- G7: infected untreated group (control positive). 3-G8: uninfected \& untreated group (control negative). Each mouse from G1 to G7 was experimentally infected with $10^{5}$ oocysts through tuberculin syringe connected to a polyethylene tube after water overnight deprivation

\section{Efficacy $=$ Oocysts shedding by control group- oocysts shedding by treated group $\mathrm{x} 100$}

\section{Oocysts shedding of control group}

Statistical analysis: Data were collected, tabulated and analyzed using Statistical Package for Social Science (SPSS) computer programs version 16. Variables were compa-
(Abdou et al, 2013). After confirmation of infection, treatment of each mouse of different groups started on day 3 post-infection and continued daily to $19^{\text {th }}$ day last experimental day. Treatment ingestion was performed by gastric gavage (Riad et al, 2009).

Feces from each group including control were collected daily separately till $19^{\text {th }}$ day acc-ording to the group to which they were assigned. Two gm from each sample was divided into 2 parts: 1st preserved in $10 \mathrm{ml}$ sodium acetate formalin (SAF) solution and homogenized for staining and the 2nd preserved in $10 \mathrm{ml} 2.5 \%$ potassium dichromate solution and homogenized for oocysts counting (Sayed et al, 2016).

Infection monitoring: a- After inoculation, all mice were daily observed for general health status, mortalities, dropping consistency and color. Pooled fecal samples from each group daily collected on the $2^{\text {nd }}$ day for assessing the prepatent period and oocyst excretion pattern (Sayed et al, 2016). Fecal pellets were collected and fecal smears were daily examined for 19 days using Modified Ziehl-Neelsen stain to detect Cryptosporidium oocysts (Henriksen and Pohlens, 1981). Efficacy of natural extracts and nitazoxanide were assessed by daily measuring of oocysts shedding count in feces to the experimental end. b- Oocyst shedding count: Oocyst number per gram feces started on $4^{\text {th }}$ day postinfection (PI) to the $19^{\text {th }}$ day. Daily output of oocysts in the feces per gram (OPG) of each group were counted (Suresh and Rehg, 1996). Number of oocysts was calculated as: (Total no. of oocysts counted $\times$ dilution factor)/(tested stool volume in gm) until the $19^{\text {th }}$ day PI. (Sayed et al, 2016).

Natural exetracts efficacy: The efficacy of of the extract were done according to Egerton (1963) by using the following formula:

red by Chi-square test. A probability level of $\mathrm{P}<0.05$ was chosen to specify significant differences, and differences between oocysts shedding among treated and control groups 
were tested by two-way ANOVA test. P-value $<0.05$ reflected significant differences.

The Ethics Committee of the Assiut University approved this study as it met the International Guiding Principles for Biomedical Research Involving Animals as issued by the Council for International Organizations of Medical Sciences The experimental animals were upheld under appropriate conditions at the animal house, Faculty of Medicine, Assiut University, Egypt.

\section{Results}

By comparing the oocyst shedding among garlic juice, black seed oil, mixture, nitaxanide (NTZ) and control + ve from the day $4^{\text {th }}$ to $19^{\text {th }}$ day, where the oocyst shedding with black seed oil was somewhat low (2000) as compared to the high shedding rate in +ve control (54000) and (6000) with NTZ. The oocyst shedding with garlic juice was (6000) and the garlic juice \& black oil combination was (4000) on the same day.

There were high significant differences between all groups and preparation of both garlic, black seed and mixture with +ve control $(\mathrm{P}=0.0000)$. Comparison between the effect of garlic juice and NTZ on Cryptosporidium oocyst output showed oocyst shedding in garlic juice and NTZ treated groups gave a higher rate in garlic juice group on days $4 \& 5$, then declined in days $7 \& 12$ as well by the end of day $18 \& 19$, without significance differences between garlic juice \& NTZ, P= 0.984 (Fig. 1). Comparison between effect of black oil and NTZ on Cryptosporidium oocyst output showed that ocyst shedding output in Black seed oil group was higher in $4^{\text {th }}$ day than NTZ, and became similar in day $5,7,8,9,10,14$ and 16 and lowered in the end in day $17,18 \& 19$, without significance differences between black oil and NTZ, P = 1.000 (Fig. 2).

Comparison between effect of garlic juice \& black oil mixture and NTZ on Cryptosporidium oocyst output showed that oocyst shedding output between garlic juice \& black oil mixture and NTZ, on day $4,5 \& 6$ was higher in garlic juice \& black oil mixture groups, then became lower on $7^{\text {th }}$ day with oocyst numbers similar on day $9,10,12 \&$ 14 to become lower again on the days 15 , $16,17,18$ till $19^{\text {th }}$ day, without significance differences between garlic juice \& black oil mixture and NTZ, P-value $=1.000$ (Fig. 3).

Comparison between effect of alcoholic black seed extract and NTZ on Cryptospori dium oocyst output showed that shedding in mice treated with alcoholic black seed extract was higher than NTZ treated one, on days $4,5 \& 6$, became lower in days $7 \& 12$. Same result was on day 16 and another rise on days $17,18 \& 19$ (Fig. 4), without significance differences between black seed alcoholic extract and NTZ, P $=0.999$.

Comparison between effect of alcoholic black arial extract, NTZ and control $+v e$ in Cryptosporidium oocyst output showed that shedding between black arial alcoholic extract and NTZ was higher in former treated group on days $4 \& 6$ to become lower on days $7,9 \& 12$, with similar numbers on days $14,15 \& 19$, without significance differences between alcoholic black arial extract and NTZ, P-value $=0.999$ (Fig. 5).

\section{Discussion}

Plants active ingredients were used as nonconventional anti-parasitosis with more attention; due to the increasing resistance development to chemical drugs against parasites and vectors (Capela et al, 2019), and parasites and microorganisms would continue to play their dangerous role in human welfare (Nicoletti, 2020).

In the present study, data showed that both garlic \& black seed extracts have an antiprotozoal effect against cryptosporidiosis as indicated by reducing oocyst shedding, but without complete oocysts elimination. The mean oocysts count of the seven treated groups varied from the $2^{\text {nd }}$ day to the $14^{\text {th }}$ day posttreatment and then reduced gradually till the experimental end on the day $19^{\text {th }}$.

Fluctuation phenomenon of oocyst shedding was reported by Hassan et al. (2019) who found a rebound increase of Cryptosporidi$u m$ oocysts number and viability or rebound 
phenomenon which included reinfection, autoinfection activation with thin-wall oocysts and/or inhibited stages reactivation. But, De Waele et al. (2012) reported that the patient could be infected with different Cryptosporidium species.

In the present study, garlic juice treated group showed a considerable reduction in Cryptosporidium oocysts mean count $(73.1 \%)$, especially in the last five experimental days. Gaafar (2011) recorded the successful eradication of Cryptosporidium oocysts from the stool of infected immunocompetent mice received garlic for two days before infection and continued for two weeks latter. Also, Hazaa et al. (2016) reported that garlic decreased the mean of Cryptosporidium spp. oocysts count in experimentally infected mice, which started from the $2^{\text {nd }}$ day post-treat ment to the experimental end on $15^{\text {th }}$ day post treatment. The mean oocysts count in (infected not treated) was high significantly $(\mathrm{P} \leq 0.05)$ along the whole experiment duration compared with treated groups.

In the present study, oocyst shedding pattern showed that garlic juice gave relatively similar effect as NTZ on the Cryptosporidium oocysts shedding. But, there was a high significance difference between garlic treated $\&$ infected untreated ones. This agreed with Wahba et al. (2003), who found that garlic extract caused a mild reduction of oocysts shedding in C. baileyi infected chickens, with significant difference in values of Cryptosporidium oocysts execration patterns between garlic treated group and non-treated control group seven days post-treatment to the experimental end on $25^{\text {th }}$ day. Abdel Megeed et al (2015) also found that garlic successfully eradicated Cryptosporidium oocysts completely by the experimental end and concluded that garlic and NTZ had a great effect on Cryptosporidium oocyst output and hosts were Cryptosporidium free. Abdel-Hafeez et al. (2015) showed that garlic significantly lowered the oocysts shedding in a pattern similar to that of NTZ. However, Schnyder et al, (2009) found that NTZ for treat- ing Cryptosporidium-infected calves did not show expected good results, as neither decreased the clinical severity nor the oocysts shedding. Fareed et al. (1996) reported that garlic was used for treating ryptosporidial HIV patients with chronic diarrhea, complete healing occurred in some patients and partial healing in others.

The efficacy of garlic in treatment of experimental cryptosporidiosis could be explained by various mechanisms of action. Chemical contents of glucose and fructose might be responsible for Allium sativum anti-parasitic action by reducing Cryptosporidium spp. intestinal colonization (Harp, 1999). Richard (2001) reported that the garlic antiprotozoal effect belonged to allicin and some other compounds that acted as antimicrobial, antioxidative, enhance phagocytosis and increased the natural killer cells activity stimulating immune system and boost body's defense mechanism during treatment. Organosulfur compounds such as allicin, diallyldisulphide, S-allylcysteine, and diallyl trisulfide are the most important constituents of garlic playing important pharmacological roles by holding up the parasite mobility, food absorption, and reproduction (Azimi et al, 2011).

Many studies determined the effects of $N$. sativa seeds on parasitic and microbial diseases. Abu El-Ezz (2005) studied the effect of $N$. sativa on Trichinella spiralis in rats, Ayaz et al. (2007) studied its effect on Hymenolepis nana in naturally infected mice, ElShenawy et al. (2008) studied its effect on Schistosoma mansoni infected mice, and Baghdadi and Al-Mathal (2011) studied its effect Eimeria stiedae infected rabbits. They reported that $N$. sativa gave a potential successful anti-parasitic treatment.

No doubt, the solvent used in extraction, its properties, physiologic absorption degree, a preservative action and ability to do extract to complex or dissociate, factors determined biologically active compounds from extracted plants, methanol, ethanol, and water were the commonest solvents used to test plants antimicrobial activity (Rojas et al. 2006). 
In the present study, extracts of $N$. sativa different parts (black seed oil, black seed alcoholic and extract of black ariel parts) were used to compare with NTZ effect on Cryptosporidium oocyst output. Black seed treated groups showed evident changes in Cryptosporidium oocysts shedding, with mean count gradually declined from $4^{\text {th }}$ day post treatment to the experimental end on $19^{\text {th }}$ day that was more clear in $10^{\text {th }} \& 11^{\text {th }}$ day, but without significant differences among groups treated with d black seed extracts and NTZ.

Some authors studied effect of $N$. sativa extracts on other parasites. El-Shenawy et al. (2008) reported prophylactic and therapeutic effect on murine toxoplasmosis and schistosomiasis mansoni. Rayan et al. (2009) found that aqueous extract of $N$. sativa gave a potential therapeutic effect against Dientamoeba fragilis. Okeola et al. (2011) reported that $N$. sativa seeds gave a significant antioxidant and good phytotherapeutic action on Plasmodium spp. Fattahi et al. (2011) reported that black seed alcoholic extract gave good efficacy against cutaneous leishmaniasis in BALB/c mice. Mahmoud-vand et al. (2014) found that $50 \mathrm{mg} / \mathrm{ml} \mathrm{N}$. sa-tiva methanolic extract incubated for $10 \mathrm{~min}$. killed $E$. granulosus protoscoleces. But, Khan et al. (2013) and Nasir et al. (2013) reported that $N$. sativa extracts did not show good effect on oocyst shedding C. parvum in naturally infected dairy calves, which may be due to changes in drug formula or alcoholic extract or protozoa's susceptibility to drug action.

Haq et al. (1999) found that $N$. sativa stimulated both CD4 positive T-cells and macrophages creating an immunomodulatory approach in man and animals. Suthar et al. (2010) found that N. sativa oil inhibited the DNA synthesis by obstruction of histone deacetylase (HDAC) enzyme interacting with the chromosomes. Mansour (2000) found that Thymo quinone (TQ), the basic component of $N$. sativa seeds volatile oil gave significant cyto-protective action.

Parasitic treatment by black seed oil mixed with other medicaments or natural products was given by Mahmoud et al. (2002) who showed encouraging outcomes of $N$. sativa in schistosomiasis treated as combined with praziquantel. Nilforoushzadeh et al. (2010) reported that a combination of honey and $N$. sativa extract in cutaneous leishmaniasis patients with glucantime was more effective with clinicall improved as compared to honey alone. Zaki and El-Amir (2018) reported that phenyl vinyl sulfone combined with $N$. sativa altered Cryptosporidium oocysts shedding than paromomycin treated one.

\section{Conclusion}

The present results hold perspective of finding a new therapeutic alternative to Cryptosporidium treatment. New and efficient natural products inhibited the Cryptosporidium growth without side effects may be very useful in the treatment.

Conflict of Interest: There was neither conflict of interest nor fund recieved.

\section{Acknowledgement}

Thanks are due to Prof. Dr. Ahmed Kamal Dyab, Department of Parasitology, Faculty of Medicine, Assiut University for his kind criticism and approved the paper, and to Asmaa Abd El-Ghafar Nasr, Poultry Diseases Department, Animal Health Research Institute, Assiut, for her kind help.

\section{References}

Abbassi, H, Wyers, M, Cabaret, J, Naciri, M, 2000: Rapid detection and quantification of Crypto-sporidium baileyi oocysts in feces and organs of chickens using a microscopic slide flotation method. Parasitol. Res. 86:179-87.

Abd El-Aziz, TH, El-Beih, NM, Soufy, H, Khalil FAM, et al, 2015: Anticryptosporidial activity of Egyptian propolis and garlic oil against Cryptosporidium oocysts in vitro. Global Vet. 15, 3:309-14.

Abdel Megeed, KN, Hammam, AM, Morsy, G H, Khalil, FM, et al, 2015: Control of cryptosporidiosis in buffalo calves using garlic (Allium sativum) and nitazoxanide with special reference to some biochemical parameters. Global Vet. 14, 5:646-55.

Abdel-Hafeez, EH, Ahmad, AK, Kamal, AM, Abdellatif, M, et al, 2015: In vivo antiprotozoan effects of garlic (Allium sativum) and ginger (Zingiber officinale) extracts on experimentally 
infected mice with Blastocystis spp. Parasitol. Res. 114:3439-44.

Abouel-Nour, MF, El-Shewehy, DMM, Hamada, SF, Morsy, TA, 2016: The efficacy of three medicinal plants; garlic, ginger and mirazid and a chemical drug metronidazole against Cryptosporidium parvum: ii- Histological changes. J. Egypt. Soc. Parasitol. 46, 1:185-200

Abu El Ezz, NMT, Khalil, AM, Shaapan, R M, 2011: Therapeutic effect of onion (Allium cepa) cinnamon (Cinnamomum zeylanicum) oils on cryptosporidiosis in experimentally infected mice. Glob. Vet. 7, 2:179-83.

Abu El-Ezz, NM, 2005: Effect of Nigella sati$v a$ and Allium cepa oils on Trichinella spiralis in experimentally infected rats. J. Egypt Soc. Parasitol. 35, 2:511-23.

Al-Naggar, TB, Gomez-Serranillos, MP, Carretero, ME, Villar, AM, 2003: Neuropharmacological activity of Nigella Sativa L. extracts. J. Ethnopharmacol. 88:63-8.

Arrowood, MJ, Sterling, CR, 1987: Isolation of Cryptosporidium oocysts and sporozoites using discontinuous sucrose and isopycnic percol gradients. J. Parasitol. 78:314-9.

Ayaz, E, Turel, I, Gul, A, Yilmaz, O, 2008: Evaluation of the antihelmintic activity of garlic (Allium sativum) in mice naturally infected with Aspiculuris tetraptera. Recent Patents AntiInfect. Drug Disc. 3, 2:149-52.

Ayaz, E, Yilmaz, H, Ozbek, H, Tas, Z, et al, 2007: The effect of Nigella sativa oil against Aspiculuris tetraptera and Hymenolepis nana in naturally infected mice. Saudi Med. J. 28, 11: 1654-7.

Azimi, H, Fallah-Tafti, M, Karimi-Darmiyan, M, Abdollahi, M, 2011: A comprehensive review of vaginitis phytotherapy. Pak. J. Biol Sci. 14:960-6.

Baghdadi, HB, Al-Mathal, EM, 2011: Anticoccidial activity of Nigella sativa. J. Food Agricul. Environ. 9, 2:10-7.

Benchaar, C, Calsamiglia, S, Chaves, AV, Fraser, GR, et al, 2008: A review of plant-derived essential oils in ruminant nutrition and production. Anim. Feed Sci. Technol. 145:209-28.

Boskabady, MH, 2002: Effect of Nigella sativa on isolated Guinea pig trachea. Arch. Iran. Med. 5, 2:103-7.

Carey CM, Lee H, Trevors JT, 2003: Biology, persistence and detection of Cryptosporidium par-vum and Cryptosporidium hominis oocyst. Water Res. 38:818-32.
Chen F, Huang K, Qin S, Zhao Y, et al, 2007: Comparison of viability and infectivity of Cryptosporidium parvum oocysts stored in potassium dichromate solution and chlorinated tap water. Vet. Parasitol. 150:13-7.

Capela, R, Moreira, R, Francisca Lopes, F, 2019: An overview of drug resistance in protozoal diseases. Int. J. Mol. Sci. 20, 22:5748. doi:

10.3390/ijms20225748

Current, WL, Garcia, LS, 1991: Cryptosporidiosis. Clinc. Microbiol. Rev. 4: 325-58.

De Waele, V, Berzano, M, Speybroeck, N, Berkvens, D, et al, 2012: Peri-parturient rise of Cryptosporidium oocysts in cows: new insights provided by duplex quantitative real-time PCR. Vet. Parasitol. 189, 2/4:366-38.

Egerton, JR, Ott, WH, Cuckler, AC, 1963: Methods for evaluating anthelmintics in the laboratory and their applications to field conditions. In: The Evaluation of Anthelmintics, by Soulsby EJL, Merck and Sharpe.

Abdel-Hady, NM, El-Hela, AA, Morsy, TA, 2014: Phenolic content of some selected Lamiaceous Egyptian Medicinal Plants: Antioxidant po-tential and ecological friend mosquito-larvicidal. J. Egypt. Soc. Parasitol. 44, 1:21-4.

EI-Shenawy, NS, Soliman, MFM, Reyad, SI, 2008: The effect of antioxidant properties of aqueous garlic extract and Nigella sativa as antischistosomiasis agents in mice. Rev. Inst. Med. Trop. S. Paulo. 50, 1:29-36.

Farah, KM, Aloji, Y, Shimizu, Y, Shiina, T, et al, 2004: Mechanisms of the hypoglycaemic and immuno-potentiating effects of Nigella sativa $L$. oil in streptozotocin-induced diabetic hamsters. Res. Vet. Sci. 77, 2:123-9.

Fareed, G, Scolaro, M, Jordan, W, Sanders, $\mathrm{N}$, et al, 1996: The use of a high-dose garlic preparation for the treatment of Cryptosporidium parvum diarrhea. Int. Conf. AIDS. 11:288-97.

Fattahi AB, Vahidi, AR, Anvari, MH, Barzegar, et al, 2011. The in vivo anti-leishmanial activity of alcoholic extract from Nigella sativa seeds. Afric. J. Microbial. Res. 5. 10.5897/11. 009. Fayer, R, 2008: General Biology. In: Fayer, R, Xiao, L, (Eds.), Cryptosporidium and Cryptosporidiosis. $2^{\text {nd }}$ ed. CRC Press, Boca Raton. FL.

Fayer, R, 2010: Taxonomy and species delimitation in Cryptosporidium. Exp. Parasitol. 124:

90-7.

Gaafar, MR, 2007: Effect of solar disinfection on viability of intestinal protozoa in drinking water. J. Egypt. Soc. Parasitol. 37:65-86. 
Gaafar, MR, 2011: Efficacy of Allium sativum (Garlic). against experimental cryptosporidiosis. Alex. J. Medic., 48, 1:59-66.

Garcia, LS, Bruckner, DA, 1997: Macroscopic and microscopic examination of fecal specimens. Diagnos. Med. Parasitol. $3^{\text {rd }}$ ed. Washington D.C. AMS Press. 11:619-26.

Haq, A, Lobob, PI, Al-Tufailc, M, Ramaa, N $\mathbf{R}$, et al, 1999: Immuno-modulatory effect of Nigella sativa proteins fractionated by ion-exchange chromatography. Int. J. Immunopharmacol. 21:283-95.

Harp, JA, 1999: Oral dosing of neonatal mice with sucrose reduces infection with Cryptosporidium parvum. J. of Parasitol. 85, 5:952-5.

Hassan D, Farghali M, Eldeek H, Gaber M, et al, 2019: Antiprotozoal activity of silver nanoparticles against Cryptosporidium parvum oocysts: New insights on their feasibility as a water disinfectant. J. Microbiol. Meth. 165:105698.

Hazaa, IK, Al-Taai, NA, Khalil, NKh, Zakri, MM, 2016: Efficacy of garlic and onion oils on murine experimental Cryptosporidium parvum infection. Al-Anbar J. Vet. Sci. 9, 2:69-74.

Henriksen, SA, Pohlenz, JF, 1981: Staining of Cryptosporidia by a modified Ziehl-Neelsen technique. Acta. Vet. Scand. 22:594-6.

Khan, A, Khan, MS, Avais, M, Ijaz, M, et al, 2013: Prevalence, hematology, and treat-ment of balantidiasis among donkeys in and around Lahore, Pakistan. Vet. Parasitol. 196: 203-5.

Kim, HC, Healey, JM, 2001: Effects of pine bark extract administered to immunosuppressed adult mice infected with Cryptosporidium parvum. Am. J. Chin. Med. 29:469-75.

Mahmoud, MR, El-Abhar, HS, Saleh, S, 2002: The effects of Nigella sativa oil against the liver damage induced by Schistosoma mansoni in mice. J. Ethnopharmacol. 79:1-11.

Mahmoudvand, H, Asadi, A, Fasihi, H, Sharififar, F, et al, 2014: In vitro lethal effects of various extracts of Nigella sativa seed on hydatid cyst protoscoleces. Iran J. Basic Med. Sci. 17 :1001-6.

Mansour, MA, 2000: Protective effects of thymoquinone and desferrioxamine against hepatotoxicity of carbon tetrachloride in mice. Life Sci. 66: 2583-91.

Masamha, B, Gadzirayi, CT, Mukutirwa, I, 2010: Efficacy of Allium sativum (Garlic) in controlling nematode parasites in sheep. Inter. J. Appl. Res. Vet. Med. 8:161-9.

Miyamoto, Y, Eckmann, L, 2015: Drug devel- opment against the major diarrhea-causing parasites of the small intestine, Cryptosporidium and Giardia. Front Microbiol. 6:1208-14

Nasir, A, Avais, M, Khan, MS, Khan, JA, et al, 2013: Treating Cryptosporidium parvum infection in calves. J. Parasitol. 99, 4:715-7.

Nicoletti, M, 2020: New solutions using natural products. Insect-Borne Diseases in the $21^{\text {st }} \mathrm{Cen}$ tury. $2020: 263-351$. Published online 2020 Aug 21. doi: 10.1016/B978-0-12-818706-7.00007-3

Nilforoushzadeh, MA, Hejazi, SH, Zarkoob, H, Shirani, L, et al, 2010: Efficacy of adding topical honey-based hydro-alcoholic extract $\mathrm{Ni}$ gella Sativa $60 \%$ compared to honey alone in patients with cutaneous leishmaniasis receiving intralesional glucantime. J. Skin Leish. 1:26-31.

Nouzarian, R, Tabeidian, SA, Toghyani, M, Ghalamkari, G, et al, 2011: Effect of turmeric powder on performance, carcass traits, humoral immune responses, and serum metabolites in broiler chickens. J. Anim. Feed Sci. 20:389-400.

Obiad, HM, Al-alousi, TI, Al-jboori, AH, 2012: The in vivo effect of some medicinal plant extracts on Cryptosporidium parasite. J. Univ. Anbar Pure Sci. 6, 3:15-26.

Okello, D, Kang, Y, 2019: Exploring antimalarial herbal plants across communities in uganda based on electronic data. Evid. Based Complement Alternat. Med. 2019: 3057180. Published online 2019 Sep 15. doi: 10.1155/2019/3057180 Okeola, VO, Adaramoye, OA, Nneji, CM, Falade, CO, et al, 2011: Antimalarial and antioxidant activities of methanolic extract of Nigella sativa seeds (black cumin) in mice infected with Plasmodium yoelli nigeriensis. Parasitol. Res. 108:1507-12.

Rayan, HZ, Eida, O, El-Hamshary, EM, Ahmed, S, 2009: Detection of Human Cryptosporidium Species in Surface Water Sources in Ismailia Using Polymerase Chain Reaction. Parasitol. Unit. J. 2:119-26.

Riad, NHA, Taha, HA, Mahmoud, YI, 2009: Effects of garlic on albino mice experimentally infected with Schistosoma mansoni: A parasitological and ultrastructural study. Trop. Biomed. 26, 1:40-50.

Richard, SR, 2001: Historical perspective on the use of Garlic. J. Nutr. 131, 3:951-4.

Rojas, JJ, Ochoa, VJ, Ocampo, S, Munoz, JF, 2006: Screening for antimicrobial activity of ten plants used in Colombian Folkovic medicine: A possible alternative in treating non-nosocomial infection. BMC Compl. Altern. Med. 6:2 
DOI:10.1186/1472-6882-6-2.

Sayed, FG, Hamza, AI, Galal, LA, Sayed, D M, et al, 2016: Virulence of geographically different Cryptosporidium parvum isolates in experimental animal model. Ann. Parasitol. 62, 3: 221-32.

Schnyder, M, Kohler, L, Hemphill, A, Deplazes, P, 2009: Prophylactic and therapeutic efficacy of Nitazoxanide against Cryptosporidium parvum in experimentally challenged neonatal calves. Vet. Parasitol. 160:146-54.

Shahiduzzaman, M, Daugschies, A, 2012: Therapy and prevention of cryptosporidiosis in animals. Vet. Parasitol. 188:203-14.

Suresh, P, Rehg, JE, 1996: Comparative evaluation of several techniques for purification of Cryptosporidium parvum oocysts from rat feces. J. Clin. Microbiol. 34:38-40.

Suthar, MP, Patel, PN, Shah, TG, Patel, RK, 2010: In vitro screening of Nigella sativa seeds for antifungal activity. Inter. J. Pharm. App. Sci. 1:84-91.

Theodos, CM, Griffiths, JK, D'Onfro, J, Fair field, A, et al, 1998: Efficacy of nitazoxanide against Cryptosporidium parvum in cell culture and in animal models. Antimicrob. Agents Chemother. 42:1959-65.

Toghyani, M, Toghyani, M, Gheisari, AA, Ghalamkari, G, et al, 2011: Evaluation of cin namon and garlic as antibiotic growth promoter substitutions on performance, immune responses, serum biochemical and hematological parameters in broiler chicks. Livest. Sci. 138:167-73. Tonkal, AMD, Morsy, TA, 2008: An update review on Commiphora molmol and related species. J. Egypt. Soc. Parasitol. 38, 3:763-96.

Toulah, FH, El-Shafei, AA, Al-Rashidi, HS, 2012: Evaluation of garlic plant and indinavir drug efficacy in the treatment of cryptosporidiosis in experimentally immune-suppressed rats. J. Egypt. Soc. Parasitol. 42: 321-8.

Wahba, AA, 2003: Studies on efficacy of garlic extract on cryptosporidiosis in experimentally infected mice. Egypt. J. Agricul. Res. 81795805.

Warrier, PK, Nambier, VP, Ramankutty, C, 2004: Indian medicinal plants- A Compendium of 500 species. Orient. Longman. Pvt. Ltd. Chennai. 4:139-42.

Wei, A, Shibamoto, T, 2010: Antioxidant/lipoxygenase inhibitory activities and chemical compositions of selected essential oils. J. Agric. Fo od Chem. 58:7218-25.

Zaki, WM, El-Amir, YO, 2018: Therapeutic efficacy of a cysteine proteases inhibitor (phenyl vinyl sulfone) either alone or combined with Nigella sativa on experimental cryptosporidiosis. J. Egypt. Soc. Parasitol. 48, 1:165-74.

\section{Explanation of figures}

Fig. 1: Cryptosporidium oocysts shedding in mice treated with garlic juice and Nitaxanide in relation to +ve control.

Fig. 2: Cryptosporidium oocysts shedding in groups treated with black oil and Nitaxanide in relation to +ve control.

Fig. 3: Cryptosporidium oocysts shedding in mice treated with garlic juice \& black oil mixture and Nitaxanide in relation to +ve control.

Fig. 4: Cryptosporidium oocysts shedding in mice treated with alcoholic black seed extract and Nitaxanide in relation to +ve control.

Fig. 5: Cryptosporidium oocysts shedding in mice treated with alcoholic black arial extract and Nitaxanide in relation to +ve control.

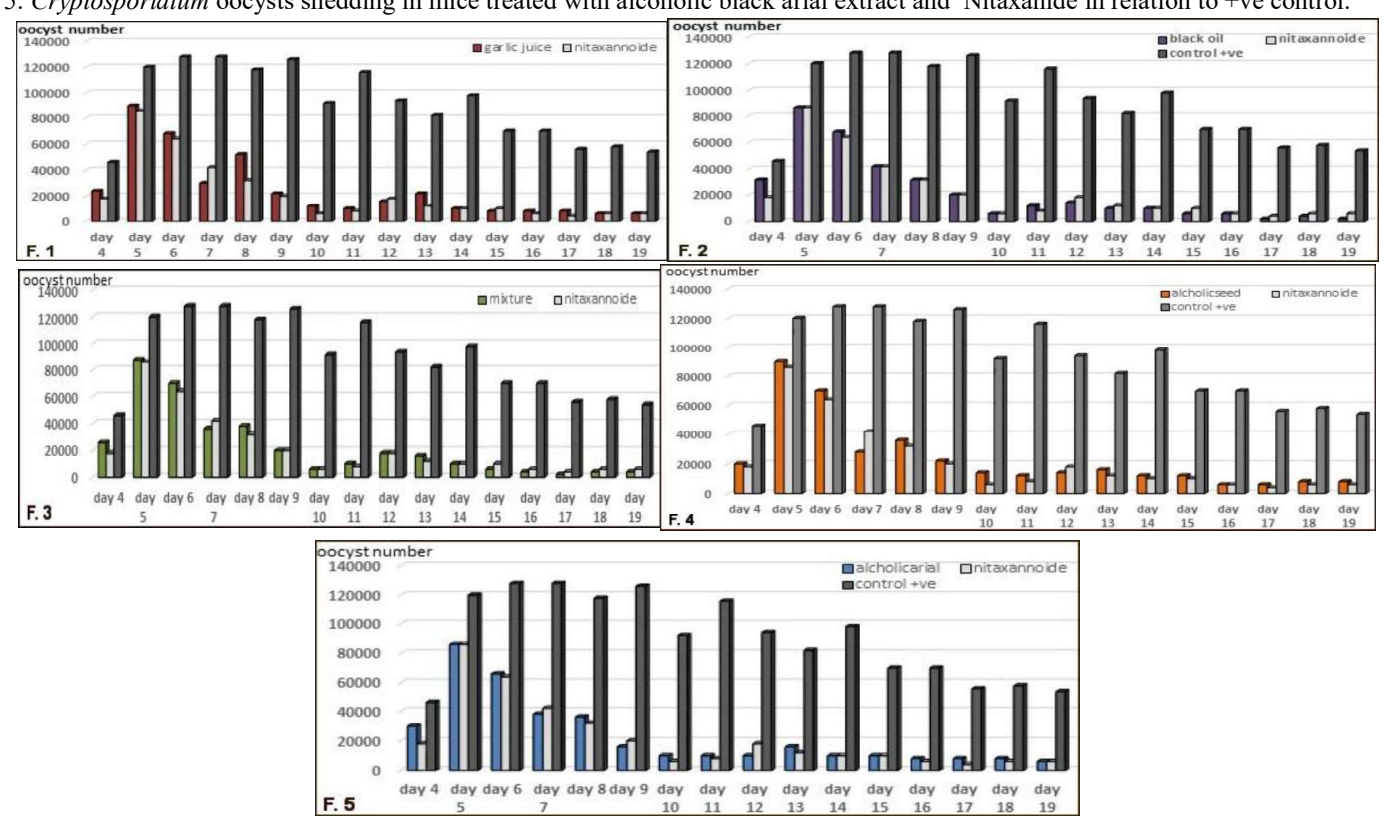

